\title{
MYOTONIC DYSTROPHY-2: UNUSUAL PHENOTYPE DUE TO A SMALL CCTG-EXPANSION
}

Finsterer $\mathrm{J}^{1, *}$, Stöllberger $\mathrm{C}^{2, \#}$, Reining-Festa $\mathrm{A}^{3}$, Loewe-Grgurin $\mathrm{M}^{4}$, Gencik $\mathrm{M}^{5}$

*Corresponding Author: Josef Finsterer, M.D., Ph.D., Krankenanstalt Rudolfstiftung, Messerli Institute, Veterinary University of Vienna, Postfach 20, 1180 Vienna, Austria. Tel. +43-1-71165-92085.

Fax.+43-1-4781711. E-mail: fifigs1@yahoo.de

\begin{abstract}
Myotonic dystrophy type 2 (MD2) is a multisystem disease, predominantly affecting the proximal limb muscles, eyes, endocrine organs, heart and intestines. Longterm asymptomatic creatine kinase (hyper-CKemia) of more than 20 years duration, in association with hyperlipidemia and diabetes, as a manifestation of MD2 has not been reported. A 52-year-old female with a history of hyper-CKemia since the age of 32 years associated with diabetes, hyperlipidemia and hyperuricemia, developed anginal chest pain and proximal muscle weakness together with clinical myotonia when opening the fists at age 51 years. Examination revealed a left anterior hemiblock, sensorimotor neuropathy, extensive myotonic discharges on needle electromyography (EMG) and a CCTG-expansion of $134 \mathrm{bp}$ on the ZNF9 gene. The family history was positive for hyper-CKemia and muscle weakness. In addition, over the previous years, she had developed vesico-ureteral reflux, cutaneous melanoma, renal cysts, cervix dysplasias, thrombocytosis, cataracts, arterial hypertension, heterozygous Factor V Leiden mutation, cholecystolithiasis, multiple ovarial cysts and vitamin D deficiency. Asymptomatic,
\end{abstract}

\footnotetext{
${ }^{1}$ Krankenanstalt Rudolfstiftung, Messerli Institute, Veterinary University of Vienna, Austria

${ }^{2}$ Department of Neurology, Krankenanstalt Rudolfstiftung, Vienna, Austria

${ }^{3}$ Neurological Department, Krankenanstalt Rudolfstiftung, Vienna, Austria

${ }^{4}$ Radiological Department, Krankenanstalt Rudolfstiftung, Vienna, Austria

${ }^{5}$ Laboratory for Human Genetics, Vienna, Austria
}

long-term hyper-CKemia in association with multisystem disease should raise the suspicion of a MD2. Rare manifestations of MD2 may be thrombocytosis, hyperuricemia, vesico-ureteral reflux, gallstones, hypertension and cyst formation. In patients with asymptomatic hyper-CKemia, needle EMG should be considered. Myotonic dystrophy type 2 may take a mild course over many years if the CCTG-expansion is short.

Keywords: Cardiac involvement; Creatine kinase (hyper-CKemia); Multisystem disease; Myotonia; Neuromuscular; ZNF9 gene.

\section{INTRODUCTION}

Myotonic dystrophy type 1 (MD1) and type 2 (MD2) are both multisystem disorders, potentially affecting each organ or tissue (Table 1) [1]. Though MD1 and MD2 frequently demonstrate elevation of creatine kinase (hyperCKemia), cholesterol, or with diabetes, long-term asymptomatic hyper-CKemia of more than 20 years duration in association with hyperlipidemia and diabetes, as in the following patient with MD2, has not been reported.

\section{CASE REPORT}

The patient is a 52-year-old, HIV-negative, Caucasian female, height $162 \mathrm{~cm}$, weight $85 \mathrm{~kg}$, with a history of surgery for vesico-ureteral reflux at ages 10 years (right), 11 years (left) and 13 years (left), diabetes first occurring during gestation at ages 21 and 22 years and requiring insulin since age 25 years, surgery for cutaneous melanoma without requiring radiation or chemotherapy at age 30 years, hyperlipidemia since at least age 31 years and hyperuricemia since age 32 years (Figure 1). At age 32 
years, initially isolated and asymptomatic hyper-CKemia, became evident (Figure 1). Since then, hyper-CKemia remained elevated throughout the next 20 years with an undulating course and a maximal value of $2262.0 \mathrm{U} / \mathrm{L}$ at age 38 years (Figure 1). At age 38 years, multiple renal cysts and hydronephrosis-I on the left side were first found on abdominal ultrasound and on abdominal computerized tomography (CT) at age 51 years (Figure 2). At age 39 years conization had to be carried out because of recurrent dysplasias papanicolaon staining(PAP) IIID followed by hysterectomy 2 days later. For recurrent thrombocytosis since age 40 years, the patient underwent a bone marrow aspiration at age 42 years, demonstrating moderate increase in megakaryocytes suggesting essential thrombocytosis. During further course, the patient developed bilateral cataracts requiring surgery at ages 41 years and 49 years, respectively, arterial hypertension since age 46 years, heterozygous Factor-V Leiden (FVL) mutation detected at age 46 years, incipient, symmetric, axonal poly-neuropathy on the lower limbs detected upon nerve conduction studies at age 47 years, cholecystolithiasis first detected at age 47 years, multiple ovarial cysts bilaterally first detected at age 51 years, and vitamin-D deficiency since age 52 years. She was smoking cigarettes. An electrocardiogram (ECG) at age 47 years was normal.

The family history was positive for hyper-CKemia [mother (300.0 U/L), sister (200.0-300.0 U/L), daughter (up to $300.0 \mathrm{U} / \mathrm{L}$ )], muscle weakness (mother, sister), and diabetes (mother). The 27-year-old son had normal CK values. Her current medication includes insulin, toujeo, metformin, candesartan, amlodipine, acetyl-salicylic acid, and B-vitamins.

At age 51 years the patient was referred for anginal chest pain and proximal, exercise-induced muscle weakness. Muscle weakness became evident when descending stairs or getting up from the floor. She reported a myotonic reaction when opening the fists. The ECG revealed a left anterior hemiblock, echocardiography and coronary angiography were normal. Clinical neurologic exam exclusively revealed distal sensory disturbances on the lower limbs, and reduced Achilles tendon reflexes. In addition to longterm hyper-CKemia, glutamate-oxalat transaminase (GOT), glutamate pyruvate transaminase (GPT), lactate dehydrogenase (LDH), hyperlipidemia, hyperglycemia, thrombocytosis, and hyperuricemia, blood tests showed reduced serum iron and elevated neutrophil granulocytes. Needle
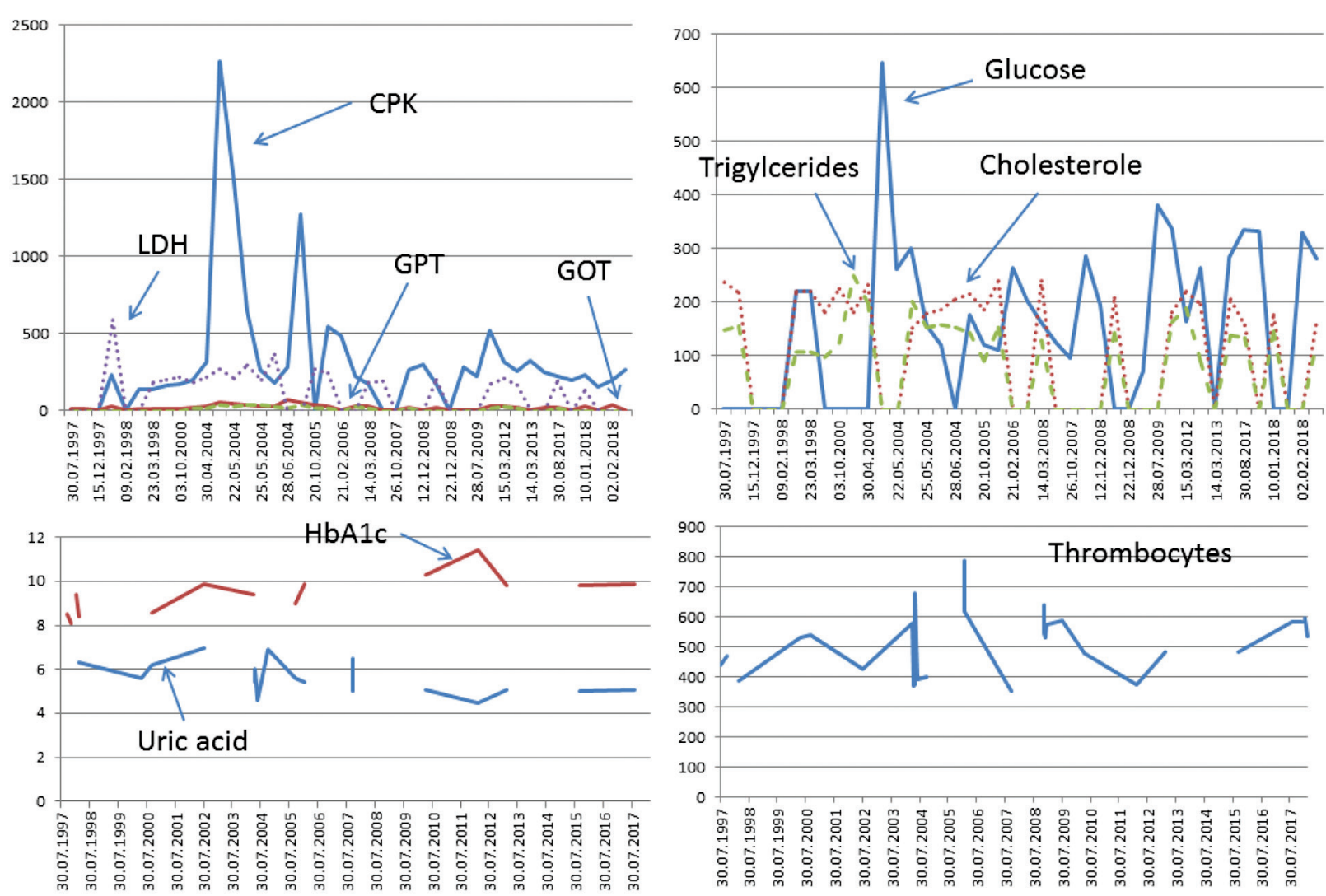

Figure 1. Course of blood values over 20 years in the described patient. Creatine phosphokinase (CPK), GOT, GPT, and LDH (upper left). Glucose triglyceride, and cholesterol (upper right). $\mathrm{Hb} \mathrm{A}_{1 \mathrm{c}}$ and uric acid (lower left). Thrombocytes (lower right). 
BALKAN JOURNAL OF MEDICAL GENETICS

Finsterer J, Stöllberger C, Reining-Festa A, Loewe-Grgurin M, Gencik M
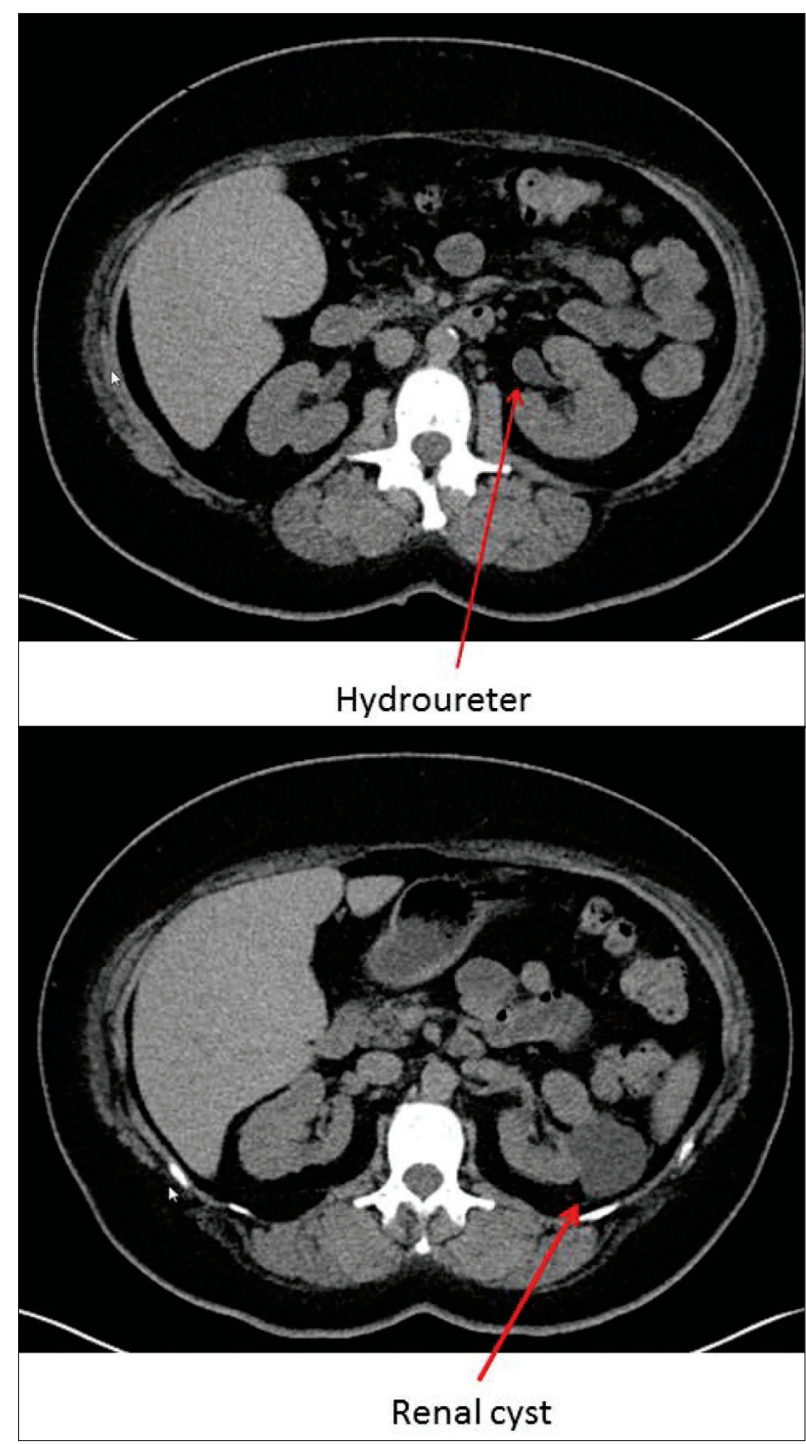

Figure 2. Abdominal CT scan showing a hydroureter and a renal cyst on the left side.

electromyograpny (EMG) of the right deltoid, left dorsal interosseous-I, and right anterior tibial muscles revealed myotonic and pseudomyotonic discharges at each recording site. Needle-EMG of the masseter muscle was normal. Genetic investigations for MD1 revealed CTG-repeat sizes of five and 10 repeats on either allele of the DPMK gene respectively. Myotonic dystrophy type 1 was thus excluded. Investigations for MD2 revealed a normal CCTG-repeat size on one allele of the ZNF9 gene (134 bp, equivalent to 34 repeats) and an abnormal expansion on the second allele. Unfortunately, the exact size of the expansion on the second allele was not provided by the laboratory. Genetic testing of the son revealed a normal CCTG repeat length on both alleles. The daughter is considering undergoing the test. Mother and sister refused to be tested. Investigations were carried out according to the Declaration of Helsinki.
Table 1. Clinical manifestations of MD1 and MD2 in the presented case and in the literature.

\begin{tabular}{|c|c|c|c|}
\hline Manifestation & $\begin{array}{c}\text { Current } \\
\text { Case } \\
\end{array}$ & MD1 & MD2 \\
\hline $\begin{array}{l}\text { Muscle: } \\
\text { myopathic face } \\
\text { limb muscle weakness } \\
\text { clinical myotonia } \\
\text { myalgias } \\
\text { muscle wasting } \\
\text { calf hypertrophy } \\
\text { hyper-CKemia }\end{array}$ & $\begin{array}{l}\text { no } \\
\text { no } \\
\text { yes } \\
\text { no } \\
\text { no } \\
\text { no } \\
\text { yes }\end{array}$ & $\begin{array}{l}\text { yes } \\
\text { yes } \\
\text { yes } \\
\text { no } \\
\text { yes } \\
\text { no } \\
\text { yes }\end{array}$ & $\begin{array}{l}\text { yes } \\
\text { yes } \\
\text { yes } \\
\text { yes } \\
\text { yes } \\
\text { yes } \\
\text { yes }\end{array}$ \\
\hline $\begin{array}{l}\text { Peripheral nerves: } \\
\text { polyneuropathy } \\
\text { autonomic dysfunction }\end{array}$ & $\begin{array}{l}\text { yes } \\
\text { no }\end{array}$ & $\begin{array}{l}\text { yes } \\
\text { yes }\end{array}$ & $\begin{array}{c}\text { yes } \\
\text { no }\end{array}$ \\
\hline $\begin{array}{l}\text { Brain: } \\
\text { cognitive impairment } \\
\text { behavioral abnormalities } \\
\text { mental retardation } \\
\text { daytime sleepiness } \\
\text { white matter lesions }\end{array}$ & $\begin{array}{l}\text { no } \\
\text { no } \\
\text { no } \\
\text { no } \\
\text { no }\end{array}$ & $\begin{array}{l}\text { yes } \\
\text { yes } \\
\text { yes } \\
\text { yes } \\
\text { yes }\end{array}$ & $\begin{array}{c}\text { no } \\
\text { no } \\
\text { no } \\
\text { yes } \\
\text { no }\end{array}$ \\
\hline $\begin{array}{l}\text { Eyes: } \\
\text { cataracts } \\
\text { low intraocular pressure } \\
\text { pigmentary retinopathy } \\
\text { epiretinal membranes }\end{array}$ & $\begin{array}{l}\text { yes } \\
\text { no } \\
\text { no } \\
\text { no }\end{array}$ & $\begin{array}{l}\text { yes } \\
\text { yes } \\
\text { yes } \\
\text { yes }\end{array}$ & $\begin{array}{l}\text { yes } \\
\text { no } \\
\text { yes } \\
\text { yes }\end{array}$ \\
\hline $\begin{array}{l}\text { Endocrine: } \\
\text { diabetes } \\
\text { hyperthyroidism } \\
\text { hyperhidrosis } \\
\text { hypogonadism } \\
\text { abortus, stillbirth }\end{array}$ & $\begin{array}{l}\text { yes } \\
\text { no } \\
\text { no } \\
\text { no } \\
\text { no }\end{array}$ & $\begin{array}{l}\text { yes } \\
\text { no } \\
\text { no } \\
\text { yes } \\
\text { yes }\end{array}$ & $\begin{array}{l}\text { yes } \\
\text { yes } \\
\text { yes } \\
\text { yes } \\
\text { no }\end{array}$ \\
\hline $\begin{array}{l}\text { Cardiac: } \\
\text { conduction defects } \\
\text { arterial hypertension } \\
\text { myocardial thickening } \\
\text { dilative cardiomyopathy } \\
\text { noncompaction } \\
\text { elevated GGT }\end{array}$ & $\begin{array}{l}\text { yes } \\
\text { yes } \\
\text { no } \\
\text { no } \\
\text { no } \\
\text { no }\end{array}$ & $\begin{array}{l}\text { yes } \\
\text { yes } \\
\text { yes } \\
\text { yes } \\
\text { yes } \\
\text { yes }\end{array}$ & $\begin{array}{l}\text { yes } \\
\text { no } \\
\text { yes } \\
\text { yes } \\
\text { yes } \\
\text { yes }\end{array}$ \\
\hline $\begin{array}{l}\text { Gastrointestinal: } \\
\text { dysphagia } \\
\text { dysmotility } \\
\text { steatosis } \\
\text { liver cirrhosis } \\
\text { gallstones }\end{array}$ & $\begin{array}{l}\text { no } \\
\text { no } \\
\text { no } \\
\text { no } \\
\text { yes }\end{array}$ & $\begin{array}{l}\text { yes } \\
\text { yes } \\
\text { yes } \\
\text { no } \\
\text { yes }\end{array}$ & $\begin{array}{l}\text { yes } \\
\text { yes } \\
\text { no } \\
\text { yes } \\
\text { no }\end{array}$ \\
\hline $\begin{array}{l}\text { Bones: } \\
\text { hyperostosis } \\
\text { foot deformities } \\
\text { small sella } \\
\text { large air sinuses }\end{array}$ & $\begin{array}{l}\text { no } \\
\text { no } \\
\text { no } \\
\text { no }\end{array}$ & $\begin{array}{l}\text { yes } \\
\text { yes } \\
\text { yes } \\
\text { yes }\end{array}$ & $\begin{array}{l}\text { no } \\
\text { no } \\
\text { no } \\
\text { no }\end{array}$ \\
\hline $\begin{array}{l}\text { Skin: } \\
\text { frontal balding } \\
\text { pilomarticoma }\end{array}$ & $\begin{array}{l}\text { no } \\
\text { no }\end{array}$ & $\begin{array}{l}\text { yes } \\
\text { yes }\end{array}$ & $\begin{array}{l}\text { yes } \\
\text { no }\end{array}$ \\
\hline $\begin{array}{l}\text { Others: } \\
\text { hydroureter } \\
\text { hyperlipidemia } \\
\text { hyperuricemia } \\
\text { thrombocytosis } \\
\text { renal cysts } \\
\text { low IgG, IgM }\end{array}$ & $\begin{array}{l}\text { yes } \\
\text { yes } \\
\text { yes } \\
\text { yes } \\
\text { yes } \\
\text { no }\end{array}$ & $\begin{array}{l}\text { no } \\
\text { yes } \\
\text { no } \\
\text { no } \\
\text { no } \\
\text { yes }\end{array}$ & $\begin{array}{l}\text { no } \\
\text { no } \\
\text { no } \\
\text { no } \\
\text { no } \\
\text { yes }\end{array}$ \\
\hline
\end{tabular}

MD1: myotonic dystrophy type 1; MD2: myotonic dystrophy type 2; hyper-CKemia: creatine kinase; IgG: immunoglobulin G; IgM: immunoglobulin $\mathrm{M}$. 


\section{DISCUSSION}

The presented patient is noteworthy for a number of aspects. First, the clinical presentation is distinct from previously reported phenotypes (Table 1). Not reported so far were thrombocytosis, hyperuricemia, vesico-urinary reflux, hydronephrosis, gallstones, hyperlipidemia, and arterial hypertension (Table 1). Whether these features were truly due to the CCTG-repeat expansion, remains speculative and requires further investigation. Thrombocytosis and hyperuricemia have not been reported in association with MD1 either. Heterozygosity of the FVL mutation has not been reported as a manifestation of MD2. Only in a single patient with MD1 has such an association been reported [2].

Second, disregarding the vesico-ureteral reflux, the patient remained asymptomatic during a period of at least 20 years since detection of hyper-CKemia. The patient developed the first symptoms attributable to MD2 not earlier than at age 51 years. She had asymptomatic hyper-CKemia during years without developing muscle symptoms. Clinical muscle manifestations (exercise-induced weakness, myotonia) occurred not earlier than age 51 years, 20 years after first recognition of hyper-CKemia. Though obese, the patient did not complain about easy fatigability or exercise intolerance.

Third, the patient developed a melanoma and dysplasias of the cervix uteri. Whether the risk of developing a neoplasm is increased in MD2 is under debate [3]. However, melanoma has been repeatedly reported in patients with MD1 [4]. There are also indications that MD1 predisposes for the development of basal cell carcinoma [5]. Though melanoma has not been reported in MD2, there is generally, both in MD1 and MD2, an increased risk of premature ageing and impaired vitamin-D homeostasis [6]. In accordance with these findings, the presented patient had vitamin-D deficiency as well. In a study of 307 patients with myotonic dystrophy, without specifying how many had MD1 or MD2, it was concluded that these patients carry an increased risk of developing thyroid cancer, melanoma, testicular carcinoma, and prostate carcinoma [7]. The mechanism underlying the association is unclear, but it can be speculated that impaired protein production due to the RNA defect, may generally lead to cell dysfunctions at multiple levels, including cell division and oncogenesis. Whether thrombocytosis reflects the increased risk of neoplasms remains speculative.

Fourth, the patient had hydroureter, ovarian cysts, and renal cysts. A hydroureter or hydronephrosis has not been previously reported in association with MD1 or MD2 [8]. Despite extensive work-up for the cause of hydroureter, the cause remained undetermined. Renal cysts have not been reported in association with MD1 or MD2 either but pancreatic cysts have rarely been observed [9]. Ovarian cysts have been rarely reported in MD1 [10] but not in MD2.

In conclusion, this case shows that asymptomatic hyper-CKemia in association with diabetes, gallstones, hyperlipidemia, hyperuricemia, renal cysts, hydroureter, arterial hypertension, and thrombocytosis should raise the suspicion of an MD2. In patients with asymptomatic hyper-CKemia needle-EMG should be considered to look for myotonic and pseudomyotonic discharges. Myotonic dystrophy type 2 may take a mild course over many years if the CCTG-expansion is short.

\section{ACKNOWLEDGMENTS}

Author contribution: Josef Finsterer: design, literature search, discussion, first draft, Claudia Stöllberger: literature search, critical review.

Declaration of Interest. The authors report no conflicts of interest. The authors alone are responsible for the content and writing of this article.

\section{REFERENCES}

1. Gourdon G, Meola G. Myotonic dystrophies: State of the art of new therapeutic developments for the CNS. Front Cell Neurosci. 2017; 11: 101.

2. Finsterer J, Stöllberger C. Myotonic dystrophy-1 complicated by factor-v (Leyden) mutation. Case Rep Med. 2015; 2015: 271639.

3. Mohamed S, Pruna L, Kaminsky P. Increasing risk of tumors in myotonic dystrophy type 1. Presse Med. 2013; 42(9): e281-e284.

4. Dalvin LA, Shields CL, Pulido JS, Sioufi K, Cohen V, Shields JA. Uveal melanoma associated with myotonic dystrophy: A report of 6 cases. JAMA Ophthalmol. 2018; 136(5): 543-547.

5. Marcoval J, Olive M, Bonfill-Orti M, Martinez-Molina L, Talavera-Belmonte A. Cutaneous neoplasms in myotonic dystrophy type 1. Dermatology. 2016; 232(6): 700-703.

6. Campione E, Botta A, Di Prete M, Rastelli E, Gibellini M, Petrucci A, et al. Cutaneous features of myotonic dystrophy types 1 and 2: Implication of premature aging and vitamin D homeostasis. Neuromuscul Disord. 2017; 27(2): 163-169.

7. Win AK, Perattur PG, Pulido JS, Pulido CM, Lindor NM. Increased cancer risks in myotonic dystrophy. Mayo Clin Proc. 2012; 87(2): 130-135. 
8. Finsterer J. Myotonic dystrophy type 1 and 2. In: Burgess VN, Editor. Progress in Muscular Dystrophy Research. Hauppauge, NY, USA: Nova Science Publishers. 2005; 149-180. (ISBN: 1-59454-375-5.)

9. Addeo A, Bini R, Viora T, Bonaccorsi L, Leli R. Von Hippel-Lindau and myotonic dystrophy of Steinert along with pancreatic neuroendocrine tumor and renal clear cell carcinomal neoplasm: Case report and review of the literature. Int J Surg Case Rep. 2013; 4(8): 648-650.

10. Mavridou P, Dimitriou V, Margaritis A, Manataki A. Anesthesia for laparoscopic surgery in a patient with myotonic dystrophy (Steinert's disease): Beneficial use of sugammadex, but incorrect use of pethidine: A case report. Acta Anaesthesiol Belg 2011; 62(2): 101-104. 